Article

\title{
Antagonistic Interactions between the African Weaver Ant Oecophylla longinoda and the Parasitoid Anagyrus pseudococci Potentially Limits Suppression of the Invasive Mealybug Rastrococcus iceryoides
}

\author{
Chrysantus M. Tanga ${ }^{1,2}$, Sunday Ekesi ${ }^{1, *}$, Prem Govender ${ }^{2,3}$, Peterson W. Nderitu ${ }^{1}$ \\ and Samira A. Mohamed ${ }^{1}$ \\ Received: 7 August 2015; Accepted: 7 December 2015; Published: 23 December 2015 \\ Academic Editors: Michael J. Stout, Jeff Davis, Rodrigo Diaz and Julien M. Beuzelin \\ 1 International Centre of Insect Physiology and Ecology (icipe), P.O. Box 30772, Nairobi 00100, Kenya; \\ ctanga@icipe.org (C.M.T.); pnderitu@icipe.org (P.W.N.); sfaris@icipe.org (S.A.M.) \\ 2 Department of Zoology and Entomology, University of Pretoria, Pretoria 0002, South Africa; \\ prem.govender@smu.ac.za \\ 3 Faculty of Health Sciences, Sefako Makgatho Health Sciences University (SMU), P.O. Box 163, \\ Ga-Rankuwa 0221, South Africa \\ * Correspondence: sekesi@icipe.org; Tel.: +254-20-863-2150; Fax: +254-20-863-2001 or +254-20-863-2002
}

\begin{abstract}
The ant Oecophylla longinoda Latreille forms a trophobiotic relationship with the invasive mealybug Rastrococus iceryoides Green and promotes the latter's infestations to unacceptable levels in the presence of their natural enemies. In this regard, the antagonistic interactions between the ant and the parasitoid Anagyrus pseudococci Girault were assessed under laboratory conditions. The percentage of parasitism of $R$. iceryoides by $A$. pseudococci was significantly higher on "ant-excluded" treatments $(86.6 \% \pm 1.27 \%)$ compared to "ant-tended" treatments $(51.4 \% \pm 4.13 \%)$. The low female-biased sex-ratio observed in the "ant-tended" treatment can be attributed to ants' interference during the oviposition phase, which disrupted parasitoids' ability to fertilize eggs. The mean foraging time, host handling time and number of successful oviposition in "ant-excluded" treatment were significantly higher compared to "ant-tended" treatments. When ant workers were allowed access to sterilized sand grains, mummified and unmummified $R$. iceryoides, they selectively removed the mummified mealybugs, indicating that they recognized the mummies as potential foods (1.2 \pm 0.46 to $7.8 \pm 1.17$ mummies at $10 \mathrm{~min}$ intervals for $2 \mathrm{~h}$ ). Percentage emergence from mummified R. iceryoides removed by the ants was significantly lower compared to emergence from mummies not exposed to ants. Although, host seeking parasitoids frequently evaded attacks, some were killed by the foraging ant workers $(2.0 \pm 0.38$ to $6.0 \pm 0.88$ at 10 min intervals for $2 \mathrm{~h}$ ). These results suggest for the first time that the presence of $O$. longinoda has a detrimental effect on the abundance, reproductive success and possibly oviposition strategy of female parasitoids, which might be a delimiting factor in field conditions if both natural enemies are to be recommended for use within the same agro-ecosystem.
\end{abstract}

Keywords: Oecophylla longinoda; Anagyrus pseudococci; Rastrococcus iceryoides; mummy mutilation; parasitoid mortality; biotic interference

\section{Introduction}

Rastrococcus iceryoides Green (Hemiptera: Pseudococcidae) was inadvertently introduced into Tanzania, Kenya and Malawi in the early 90s, where it is potentially posing a serious threat especially on mango production [1-4]. In its native range of Southern Asia, R. iceryoides is believed to be highly 
polyphagous compared to $R$. invadens, which was first detected in 1982 and spread rapidly invading the coastal regions of most West and Central African states causing overwhelming losses of $50 \%-90 \%$ of mango, coupled with social and cultural problems [5]. The host range of $R$. invadens has been well documented with 45 plant species from 22 families classified as forest trees, vegetables, shade trees, fruit trees and ornamental plants [6] compared to more than 80 known host plants from 35 families in Southeast Asia [1,7] and 29 host plants from 16 families in Kenya and Tanzania for R. iceryoides [4]. However, R. invadens was brought under control in West and Central African states by release of two exotic encyrtid wasps, Gyranusoides tebygi Noyes and Anagyrus mangicola Noyes, from India [5,8].

The feeding behaviour of $R$. iceryoides on their associated host plants causes premature leaf drops, shedding of inflorescences and fruit-lets, as well as severe twig dieback effect $[4,9]$ Rastrococcus iceryoides has a high fecundity with nine to ten generations per year, and excretes abundant honeydew on which sooty mold develops [4,10], thus reducing fruit marketability. As a result of the development of sooty mould, export opportunities are often impaired due to quarantine regulations [11]. In Tanzania, Kenya and Malawi, mango losses due to this pest can range from $30 \%$ to complete crop failure in unmanaged orchards [3,4]. Since its accidental introduction into Africa in the early 1990s [1,2], management has relied largely on repeated applications of insecticides, but the use of chemical insecticides are not always effective for the management of several species of mealybug due to the heavy layers of waxy coating that shield their body [12]. The egg stage of $R$. iceryoides in particular and several other mealybug species are protected by a thick waxy ovisac [4,13], which most insecticides cannot penetrate [14]. This combined with the extremely wide host range makes it almost impossible to have a spraying program capable of bearing the cost and coping with the practicalities of treating the whole range of infested plants in an affected area [15]. As a result, the most common method used by some growers is cutting down of heavily infested mango trees, while others have abandoned mango cultivation altogether.

Therefore, as an alien invasive pest species in Africa, R. iceryoides is an obvious target for classical biological control. The exploration for natural enemies of $R$. iceryoides in its putative home of origin is currently being undertaken by the African Fruit Program (AFFP) under the umbrella of the International Centre of Insect Physiology and Ecology (icipe) and this will be immediately followed by importation of promising species to Africa for evaluation and ultimate release. However, before embarking on the introduction of coevolved natural enemies from the indigenous home of the pest, the composition as well as the efficacy of indigenous natural enemies, which may have formed new associations with this pest in Kenya and Tanzania, was established [4,16]. These studies revealed that Anagyrus pseudococci Girault (Hymenoptera: Encyrtidae) was the most widely distributed indigenous primary parasitoid of $R$. iceryoides in both countries accounting for $95 \%$ of the overall parasitism on the pest [4]. In the light of this knowledge, the potential use of A. pseudococci in augmentative biological control of $R$. iceryoides is currently under evaluation at icipe, Nairobi, Kenya.

On the other hand, the African weaver ants Oecophylla longinoda Latreille (Hymenoptera: Formicidae) are the most dominant and important ants in tree canopies of the humid tropics of Africa [17,18]. The mango mealybug also has a spatial refuge under tree canopies, where it is protected from extreme temperatures, natural enemies and insecticide applications [4]. Several studies have shown that ants tend honeydew-producing Hemipteran insects such as mealybugs to access a renewable and defensible source of carbohydrates energy-rich food [19]. In return, the ants render protection against parasitoids, predators and even their competitors [20,21], as well as sanitation [22]. The relative effectiveness of the Africa weaver ant O. longinoda in reducing the incidence of predation and parasitization in different Homoptera has rarely been examined. By providing protection to the mealybugs from natural enemies, the presence of certain ant species can be detrimental to the impacts of biological control $[4,23,24]$. It is important to note that the ultimate success of both indigenous and exotic biological control agent is crucial and depends largely on their relationships with resident species in the invaded area as well as many other environmental factors [25]. This implies that if there is any harmful biotic interference between resident organisms 
and the released biological control agent, then establishment and/or efficacy of that biological control agent can be affected negatively [26]. For example, Chacón et al. [25] has shown that biotic interference can be responsible for close to $20 \%$ of failures of most classical biological control programs.

The use of predatory African weaver ant $O$. longinoda has recently been advocated as a component for inclusion within mango fruit fly integrated pest management programs in Africa; as fruit damage can be reduced as a function of the ant abundance [18,27]. Several studies have shown that $O$. longinoda has the ability to significantly reduce pest damage in many tropical tree crops [20,28-32] and are in this way known to improve fruit quality [30,33]. Although ants are excellent natural predators and can be used as biological controls for some pests as described above, virtually all ant species that prey on insect pests also possess some potential disadvantages [34]. For example, recent reviews have demonstrated that O. longinoda and other ant species are relatively indiscriminant, omnivorous predators that attack beneficial insects in addition to pests and may play a key role in reducing the efficacy of some natural enemies in several agro-ecosystems [35-38]. Oecophylla longinoda, in particular, is highly aggressive and strongly predaceous, using their considerable strength and cooperative ability to capture a wide range of insect prey that venture onto their colonies, spread over large territories on canopies of host trees [39]. Ant foraging on plant canopies has been reported to significantly reduce natural enemy activities and promote mealybug infestation to a significant level [40]. The disruption of parasitoid species activities can be attributed to the differences in their behavioural avoidance of ants, length of oviposition period, and their ease of disturbance during oviposition [41,42].

Although most parasitoids are severely hampered by aggressive ant species, Way [43] pointed out that $O$. longinoda workers do not attack very small insects such as parasitoids (Coccophagus spp.) of their attended scale insect, Saissetia zanzibarensis William (Homoptera: Coccidae). Beside the observation by Way [43], no other information exists in the literature on the biotic interference likely to occur between other native parasitoids and the resident $O$. longinoda, to provide basic information for the development of reliable and cost-effective future management interventions of hemipteran pests in the presence of these ants. As part of an ongoing project on integrated pest management (IPM) of major mango pests, the purpose of this study was to examine under laboratory conditions (i) the effect of $O$. longinoda on the incidence of parasitism of $R$. iceryoides by $A$. pseudococci and parasitoid emergence; (ii) host-handling time and oviposition success of $A$. pseudococci in the presence and absence of $O$. longinoda; (iii) effect of $O$. longinoda abundance on parasitoid emergence based on close examination of mummified $R$. iceryoides removed by the ants; (iv) assess mortality inflicted by $O$. longinoda on the parasitoids and behavioural responses displayed by the parasitoid to evade encounters with workers of $O$. longinoda.

\section{Experimental Section}

\subsection{Mealybug and Parasitoid Wasp Colonies}

The colony was initiated from a cohort of 300 adult $R$. iceryoides that were collected from a mango tree in Matuga, $\left(04^{\circ} 11^{\prime} 02.5^{\prime \prime}\right.$ S, 039 33'38.4" E, $109 \mathrm{~m}$ above sea level), Coast Province of Kenya on the 13 February 2008 and transported to icipe, Nairobi, Kenya. In the laboratory at icipe, butternut squash were surface sterilized with $5 \%$ sodium hypochloride, followed by three rinses in sterile distilled water to prevent fungal growth and later air dried for $24 \mathrm{~h}$. Thereafter, the surface sterilized butternuts were infested with the mealybugs collected from the field. For colony maintenance, bi-weekly infestation of 10-20 butternut squash was carried out, and after every six months, wild populations of $R$. iceryoides from the field were introduced to ensure a broader genetic diversity in the laboratory colonies. The mealybugs were maintained on butternut squash for approximately 20 generations to allow adaptation to their new host. Cultures were maintained at ambient conditions $\left(26 \pm 2{ }^{\circ} \mathrm{C}, 60 \%-70 \%\right.$ relative humidity $(\mathrm{RH})$, and photoperiod of $\left.12 \mathrm{~h} \mathrm{L:} 12 \mathrm{~h} \mathrm{D}\right)$. Before the start of the experiments, mealybugs were collected from the stock colony and maintained until third instar 
nymphs, which are the most preferred developmental stage for oviposition by A. pseudococci [44]. The parasitoid colony was initiated from mummified $R$. iceryoides, collected from the same mango tree. The mummified mealybugs were kept in a well-ventilated transparent Perspex cage $(30 \mathrm{~cm}$ length $\times$ $30 \mathrm{~cm}$ width $\times 30 \mathrm{~cm}$ height) with a moistened cotton ball in the laboratory at room temperature. The emerged parasitoids (72 females and 21 males) were allowed to mate for $48 \mathrm{~h}$ and then reared on third instar nymphs and adults of $R$. iceryoides maintained on butternut squash in a well-ventilated Perspex cage $(30 \mathrm{~cm}$ length $\times 30 \mathrm{~cm}$ width $\times 30 \mathrm{~cm}$ height). The parasitoids were provided with fine drops of pure honey streaked on the top-side of the cages as food and moist cotton wool as water sources. The parasitoid colony was periodically refreshed every six months with field-collected insects and maintained at ambient conditions $\left(26 \pm 2{ }^{\circ} \mathrm{C}, 60 \%-70 \% \mathrm{RH}\right.$ and a 12:12 (L:D) photoperiod).

Before the start of the experiment, 50 adult wasps were collected from the stock colony weekly and released into another Perspex cage $(30 \mathrm{~cm}$ length $\times 20 \mathrm{~cm}$ width $\times 20 \mathrm{~cm}$ heights $)$ containing two butternuts, each infested with 500 third instar nymphs of $R$. iceryoides. Parasitoids were maintained on butternut squash for at least 10 generations (from egg to adults) to allow them to adapt and to remove maternal effects [45], thus minimizing the effects of associative learning during the experiments. At the start of the experiment, 12 days after the release of the parasitoids, mummies were collected from the butternut squash and individually placed in gelatin capsules, and newly emerged parasitoids were used for the experiments.

\subsection{Ant Colonies}

Several ant nests of $O$. longinoda containing major and minor workers together with queens were collected from a tree at Muhaka $\left(04^{\circ} 19^{\prime} 24.8^{\prime \prime}\right.$ S, 039 $31^{\prime} 35.3^{\prime \prime}$ E, $30 \mathrm{~m}$ above sea level), Coast Province, Kenya on 14 February 2008. The ant nests were carefully transported to icipe and then placed on branches of potted Ficus benjamina L. (Family: Moraceae) seedlings in a screen-house $(2.8 \mathrm{~m}$ length $\times 1.8 \mathrm{~m}$ width $\times 2.2 \mathrm{~m}$ height), since different colonies have been reported to be mutually antagonistic [39]. The potted F. benjamina plants were maintained on tables $(245 \mathrm{~cm}$ length $\times 78 \mathrm{~cm}$ width $\times 75 \mathrm{~cm}$ height). The edges of the tables were smeared with Tanglefoot ${ }^{\circledR}$ insect barrier paste (The Tanglefoot Company, Grand Rapids, MI, USA) while the feet of the table were placed in containers filled with soapy water to keep away predators. The O. longinoda colonies were provided with living insect food sources (for example, dipterans' larvae and adults, termites, caterpillars, lepidopteran adults, grasshoppers, worms, etc.) three times a week. Studies have shown that Oecophylla ants fed exclusively with insects would result in highly aggressive ants [46]. Other high protein food sources, especially fish intestines, were also provided twice a week to augment the weaver ant population. Cotton wool balls soaked in diluted honey solution were also provided and replaced every $48 \mathrm{~h}$. The rearing conditions at the screen house were maintained at $22.3 \pm 5.07^{\circ} \mathrm{C}$, $40 \%-80 \%$ RH and $12 \mathrm{~h} \mathrm{L:} 12 \mathrm{~h}$ D photoperiod.

\subsection{Effect of O. longinoda on Parasitism of R. iceryoides by A. pseudococci and Parasitoid Sex Ratio}

Butternut fruits infested with 100 third instar nymphs of $R$. iceryoides were used in this experiment. A total of 100 workers of O. longinoda were transferred into the cages holding the mealybug-infested butternut fruits and allowed to forage for $3 \mathrm{~h}$. Thereafter, 10 three-day old female and 10 male wasps were aspirated from the rearing cages and gently introduced into the experimental cages together with food as described above. An ant-free cage with $R$. iceryoides and parasitoids only was used as "control". After $24 \mathrm{~h}$ exposure, the ants and parasitoid wasps were removed. Cages with exposed $R$. iceryoides were then allowed to stand for 10 days, after which mummified $R$. iceryoides were recorded daily. When parasitoid emergence was completed, the number of the mummies with parasitoid exit holes and numbers of unenclosed mummies were recorded. The latter were then dissected under the microscope and their contents (dead mealybug, dead parasitoid, empty shell, or undifferentiated mass) were recorded. Sex ratio was calculated as the proportion of females to the 
total number of emerged wasps. The experiment was maintained at $26 \pm 2{ }^{\circ} \mathrm{C}, 60 \%-70 \% \mathrm{RH}$ with a $12 \mathrm{~h}: 12 \mathrm{~h}$ (L: D) photoperiod. The experiment was replicated 10 times.

\subsection{Host Handling Time and Oviposition Success of A. pseudococci in the Presence and Absence of O. longinoda}

Newly emerged wasps were sexed, mated and fed with pure honey and water as described above. In this experiment, only $72 \mathrm{~h}$ old host-deprived female wasps were used because high egg load is a major parameter of foraging motivation and oviposition pressure $[16,47,48]$. The experiment consisted of "ant-tended" and "ant-excluded" treatments with 100 adult O. longinoda workers used from each replicate of the treatments. Observation period for each treatment began when a single mated female wasp was introduced into the cage containing butternut infested with 50 unparasitized third instar nymphs of $R$. iceryoides. After the wasp was introduced into the experimental arena, qualitative descriptions of the time spent for each observational parameter was recorded. In this study, host-handling time is defined as the sum of adult parasitoid female examination of $R$. iceryoides, probing and drilling as well as oviposition time during the observation period in both "ant-tended" and "ant-excluded" treatments. Following each host encounter, host-handling was divided into three responses: (a) host examination-for $A$. pseudococci, when a foraging female wasp encountered a host, they exhibited a stereotypical host examination process before rotating her body to face away from the host, showing clearly that it had recognized the potential host; (b) ovipositor probing and drilling-occurs when the foraging female wasp flexed the tip of her abdomen such that the tip of the ovipositor touches the host body plus a fast and rhythmical insertion of ovipositor into the host and (c) oviposition-characterized by a pumping movement of the abdomen and ending up with a strong and jerky withdrawal of the ovipositor (i.e., host haemolymph exudes from the oviposition puncture). The experiment was terminated when the parasitoid was caught by ants or after an hour.

During the process of host-handling, R. iceryoides often exhibited a defensive response, which included raising and shaking its abdomen violently and rapidly in order to throw the parasitoid off its body or pulling its sucking mouth part and moving backward. This behavioural tendency exhibited by the host usually led to host rejection without initiating probing, drilling or oviposition. Therefore, after oviposition was completed during each interactive phase, stung $R$. iceryoides (i.e., mealybug bleed haemolymph) were circled with a permanent marker pen and allowed to continue feeding on the butternut for three days. From direct observation it cannot be determined whether each drilling bout made by the parasitoid resulted in oviposition or how many eggs were deposited. Therefore, the stung mealybugs from the different treatments ("ant-tended" and "ant-excluded" treatments) were dissected in phosphate buffer solution (PBS) using Leica MZ 125 Microscope (Leica Microsystems, Heerbrugg, Switzerland), fitted with Toshiba 3CCD camera. The parasitoid eggs were then observed using an Auto Montage software (Syncroscopy, Synoptics group, Cambridge, UK) fitted to the computer at magnification of X25. The number of parasitoid eggs oviposited in each mealybug was counted microscopically to determine oviposition success. Each A. pseudococci female was observed only once, with a total of 15 female wasps in each treatment.

\subsection{Effect of O. longinoda Abundance on Parasitoid Emergence}

Prior to the experiments, five different groups of $O$. longinoda $(1,5,10,15$ and 20 ants) were fasted for $24 \mathrm{~h}$ in the laboratory. At the start of the experiment, the different ant groups were carefully introduced into their respective transparent Perspex cages $(60 \mathrm{~cm}$ length $\times 60 \mathrm{~cm}$ width $\times 50 \mathrm{~cm}$ height) and allowed to interact for $30 \mathrm{~min}$. The Perspex cages had a small opening by the side ( $2 \mathrm{~cm}$ in diameter) through which a cord (1 cm thick) linked it to another cage of similar size, $90 \mathrm{~cm}$ away from the experimental arena to represent the ant's nest. The negative control consisted of 30 sterilized sand grains (approximately, $3 \mathrm{~mm}$ diameter) placed on top of carefully cut circular portions of the bottom of butternut fruits in Petri dishes $(9 \mathrm{~cm}$ diameter). The positive control was a group of 30 unparasitized $R$. iceryoides randomly placed on circular cut portions of butternut, as 
described above, $24 \mathrm{~h}$ prior to the experiment. The test treatment comprised of 30, eight-day-old mummified $R$. iceryoides containing A. pseudococci immature instars also randomly placed on the circular cut portions of butternuts in Petri dishes. After, $30 \mathrm{~min}$ following the introduction of the ant groups into their respective cages, the Petri dishes containing mummified $R$. iceryoides, unparasitized $R$. iceryoides and sterilized sand grains were gently introduced to the center of the experimental arena of the ants and allowed an interaction time of $5 \mathrm{~min}$. Thereafter, continuous observations were made at every $10 \mathrm{~min}$ interval for a total duration of $2 \mathrm{~h}$ to record the number of mummified $R$. iceryoides, unparasitized R. iceryoides and sand grains removed from the Petri dishes by the ant workers and transported successfully to the next cage connected with the cord as described above. The Petri dishes were randomly oriented at the start of each replicate in order to randomize the sequence of the discs. After each experiment, the ants were removed and the total number of mummified $R$. iceryoides transported over the $2 \mathrm{~h}$ observation period by the different ant groups was kept separately until emergence of the adult parasitoid wasps. Additional Petri dishes containing 30 mummified $R$. iceryoides not exposed to the ant workers were introduced as control for the adult parasitoid eclosion experiments. Emerged parasitoid wasps were counted and expressed as a percentage of the initial number of mummified R. iceryoides removed by the ant workers at the end of each experiment. The numbers of unenclosed mummies were recorded and dissected under the microscope as described above. Five replicates of this experiment were conducted for each cohort of ants.

\subsection{Behavioural Experiment of Parasitoid Wasp}

Before the start of the experiment, five butternut fruits infested with 200 third instar nymphs of R. iceryoides each were introduced into Perspex cages $(90 \mathrm{~cm}$ length $\times 90 \mathrm{~cm}$ width $\times 60 \mathrm{~cm}$ height). Thereafter, 100 workers of $O$. longinoda that were fasted for $24 \mathrm{~h}$ were transferred into each cage and allowed to forage for $3 \mathrm{~h}$ before 30 three-day old mated $\mathrm{A}$. pseudococci were introduced. Observations were made $10 \mathrm{~min}$ after the release of the parasitoid whereby the number of ants on the whole butternut and number of host-seeking parasitoids injured or killed by O. longinoda were recorded at $10 \mathrm{~min}$ intervals for $2 \mathrm{~h}$. Additional cages containing 30 three-day mated A. pseudococci not exposed to the ant workers were used as "control" for the adult parasitoid mortality experiment.

Responses of adult $A$. pseudococci toward O. longinoda workers were classified into the following four behaviours: (1) fly away-in which the female flee away from the infested butternut on encounter with the ant; (2) jump away-on encounter with the ant without leaving the infested butternut; (3) change of walking direction-to avoid physical contact with the approaching ants; and (4) ignoring - the wasp continued its activities although at close contact with the ant. Observations were made at $10 \mathrm{~min}$ intervals for a total duration of $2 \mathrm{~h}$ to record the number of parasitoids that showed each behavioural response. Dead parasitoids were replaced immediately to make sure that same number of parasitoids was observed at each time throughout the $2 \mathrm{~h}$ observation period. This experiment was replicated five times.

\subsection{Statistical Analysis}

Data on percentage of parasitism, percentage of emergence, sex ratio, number of ovipositor penetrations of host, successful and unsuccessful oviposition, and the duration of behavioural sequences (searching time and host handling time) in both "ant-tended" and "ant-excluded" treatments were subjected to Student's $t$-test. The percentage of parasitoid emergence after allowing access of mummified R. iceryoides containing immature stages of $A$. pseudococci to the different ant treatments were subjected to a one-way analysis of variance (ANOVA). The number of mummified $R$. iceryoides removed by different $O$. longinoda groups, the number of dead adult parasitoids killed by O. longinoda and behavioural responses displayed by the parasitoid to evade attack by O. longinoda at different time intervals were analyzed using a repeated measures analysis of variance. Data on percentages obtained during the study were arcsine transformed to comply with homogeneity 
of variance and normality assumptions before subjecting them to the various statistical analyses described above. Means were separated using Student Neuman-Keuls test and the alpha level was $p<0.05$ to indicate significance. The analyses were implemented using R 2.13.1 [49].

\section{Results}

\subsection{Effect of O. longinoda on Parasitism of R. iceryoides by A. pseudococci, Parasitoid Emergence and Parasitoid Sex Ratio}

The percentage parasitism of $R$. iceryoides by A. pseudococci in the "ant-excluded" treatment was significantly higher compared to the "ant-tended" treatment (Table 1). The percentage emergence of A. pseudococci was also significantly higher in "ant-excluded" treatments compared to "ant-tended" treatments. The offspring sex ratio was female-biased and significantly different between the "ant-excluded" and "ant-tended" treatments (Table 1).

Table 1. Mean $( \pm \mathrm{SE})$ percentage parasitism, adult parasitoid eclosion and sex ratio of Anagyrus pseudococci after $24 \mathrm{~h}$ exposure period to third instar nymphs of Rastrococcus iceryoides in the presence and absence of $O$. longinoda.

\begin{tabular}{lccccc}
\hline \multirow{2}{*}{ Parameters } & \multicolumn{2}{c}{ Treatment } & \multicolumn{3}{c}{$\boldsymbol{t}$-Test } \\
\cline { 2 - 6 } & Ant-Tended & Ant-Excluded & $\boldsymbol{t}$ & $\boldsymbol{d f}$ & $\boldsymbol{P}$ \\
\hline Parasitized Nymphs (\%) & $51.4 \pm 4.13^{\mathrm{b}}$ & $86.6 \pm 1.31^{\mathrm{a}}$ & 8.45 & 18 & $<0.0001$ \\
Adult parasitoid & $85.42 \pm 2.72^{\mathrm{b}}$ & $94.54 \pm 0.55^{\mathrm{a}}$ & 3.34 & 18 & 0.0069 \\
eclosion (\%) & $62.2 \pm 3.28^{\mathrm{b}}$ & $71.67 \pm 1.71^{\mathrm{a}}$ & 2.54 & 18 & 0.0204 \\
Sex ratio (\%) &
\end{tabular}

Within the same rows means followed by different letter are significantly different at $p \leqslant 0.05$.

\subsection{Host-Handling Time and Oviposition Success of A. pseudococci in the Presence and Absence of O. longinoda}

The average host searching time by A. pseudococci on "ant-tended" experimental arena (treatment) was significantly longer compared to the "ant-excluded" treatments. Upon contact with the host, A. pseudococci required significantly longer time to complete all sequences of host examination and oviposition activities on a single host in "ant-excluded" treatment and in "ant-tended" treatment (Table 2).

Table 2. Mean $( \pm S E M)$ host searching time, host handling time, ovipositor penetration and successful oviposition per $\mathrm{h}$, when Anagyrus pseudococci females foraged in the presence or absence of Oecophylla longinoda.

\begin{tabular}{lccccc}
\hline \multirow{2}{*}{ Parameters } & \multicolumn{2}{c}{ Treatment } & \multicolumn{3}{c}{$\boldsymbol{t}$-Test } \\
\cline { 2 - 6 } & Ant-Tended & Ant-Excluded & $\boldsymbol{t}$ & $\boldsymbol{d f}$ & $\boldsymbol{P}$ \\
\hline Searching time (seconds) & $440.9 \pm 28.42^{\mathrm{a}}$ & $334.5 \pm 25.83^{\mathrm{b}}$ & 2.77 & 38 & 0.0086 \\
Host handling time (seconds) & $71.07 \pm 1.68^{\mathrm{b}}$ & $79.53 \pm 2.56^{\mathrm{a}}$ & 2.72 & 28 & 0.0112 \\
No. of ovipositor penetration/h & $5.87 \pm 0.72^{\mathrm{b}}$ & $11.27 \pm 1.29^{\mathrm{a}}$ & 7.18 & 28 & 0.0093 \\
No. of successful oviposition/h & $4.13 \pm 0.70^{\mathrm{b}}$ & $9.87 \pm 1.25^{\mathrm{a}}$ & 4.02 & 28 & 0.0006 \\
\hline
\end{tabular}

Within the same rows means followed by different letter are significantly different at $p \leqslant 0.05$.

Dissection of exposed R. iceryoides from "ant-tended" and "ant-excluded" treatments showed that $A$. pseudococci deposited a single egg with each oviposition bout. However, it was not uncommon for A. pseudococci to drill in different locations on the same host. Anagyrus pseudococci achieved a significantly higher number of successful ovipositions in "ant-excluded" treatments compared to "ant-tended" treatments (Table 2). 


\subsection{Effect of O. longinoda Abundance on Parasitoid Emergence}

When ant workers were allowed access to sterilized sand grains, mummified and unmummified mealybugs, they selectively removed the mummified mealybugs. Although, the different ant-groups were occasionally observed to perform antennal examination of the sand grains and unmummified mealybugs, none of these was transported out of the experimental arena to the next cage $(90 \mathrm{~cm}$ away). When comparing the number of mummies removed across the different time intervals by the different ant groups, the 20 ant-group removed and transported a significantly higher number of mummies compared to its counterparts except at the intervals of 40 and $60 \mathrm{~min}$. The interaction between the different ant-groups and number of mummified $R$. iceryoides transported by the ants over the $2 \mathrm{~h}$ observation period was significantly different $(F=8.13$; $\mathrm{df}=33,396 ; p<0.0001)$. No mummified mealybugs was removed by the 1 and 5 ant-group treatment within the first 50 and $70 \mathrm{~min}$ of observation, respectively. The number of mummified mealybugs removed at the 90th min $(F=342.46 ; \mathrm{df}=4,182 ; p<0.0001)$ and 100 th $(F=179.87 ; \mathrm{df}=4,98 ; p=0.0038)$ by the 20 ant-group was significantly higher compared to the other ant-group treatments. Ant encounters with mummified $R$. iceryoides were always followed by an antennal examination before the ant workers finally transported the mummies away (Figure 1). During the $2 \mathrm{~h}$ observation period, the mean number of mummified $R$. iceryoides removed and transported by the different ant groups was observed to increase with time (Figure 2). There was a significant difference in the number of mummified $R$. iceryoides removed by the worker ants when compared across the different periods of observation $(F=2.79 ; \mathrm{df}=44,220 ; p=0.0104)$.
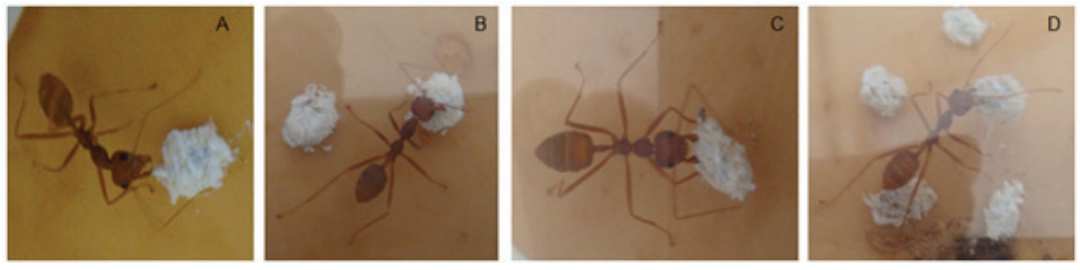

Figure 1. Oecophylla longinoda worker encounters with mummified mealybugs were always followed by an antennal examination (A) before transportation (B-D), indicating that they perceived the mummies as a potential food source.

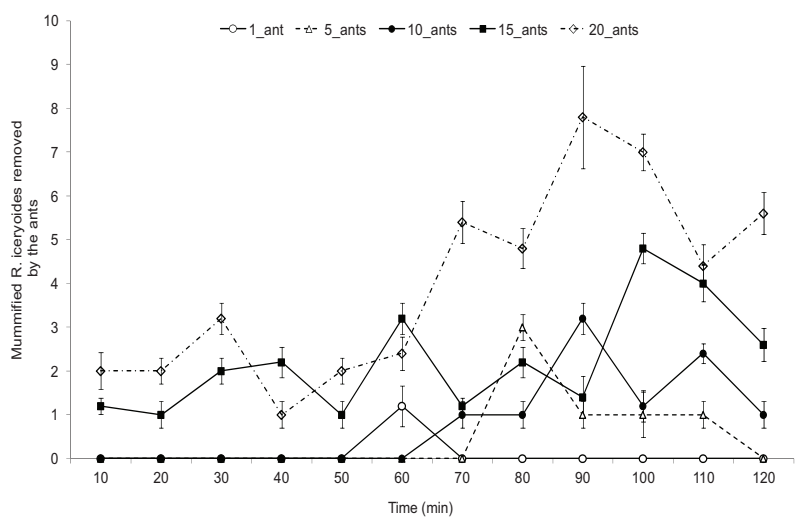

Figure 2. Mean number ( \pm standard error) of mummified Rastrococcus iceryoides removed and transported by the different Oecophylla longinoda ant groups (treatments) from the foraging cages at $10 \mathrm{~min}$ intervals over a $2 \mathrm{~h}$ observation period.

Mummified mealybugs removed by the single ant treatment had less mutilation as evident by a high percentage emergence of adult A. pseudococci $(93.33 \% \pm 6.29 \%)$ compared to that for the 20 ant-group treatment $(54.09 \% \pm 5.78 \%)$ (Figure 3$)$. There was a significant difference in the percentage emergence of parasitoids among the different ant groups $(F=7.38 ; \mathrm{df}=4,124 ; p<0.0001)$. 
No significant differences of percentage emergence were observed between 1, 5 and 10 ant-group treatments compared to the control (Figure 3).

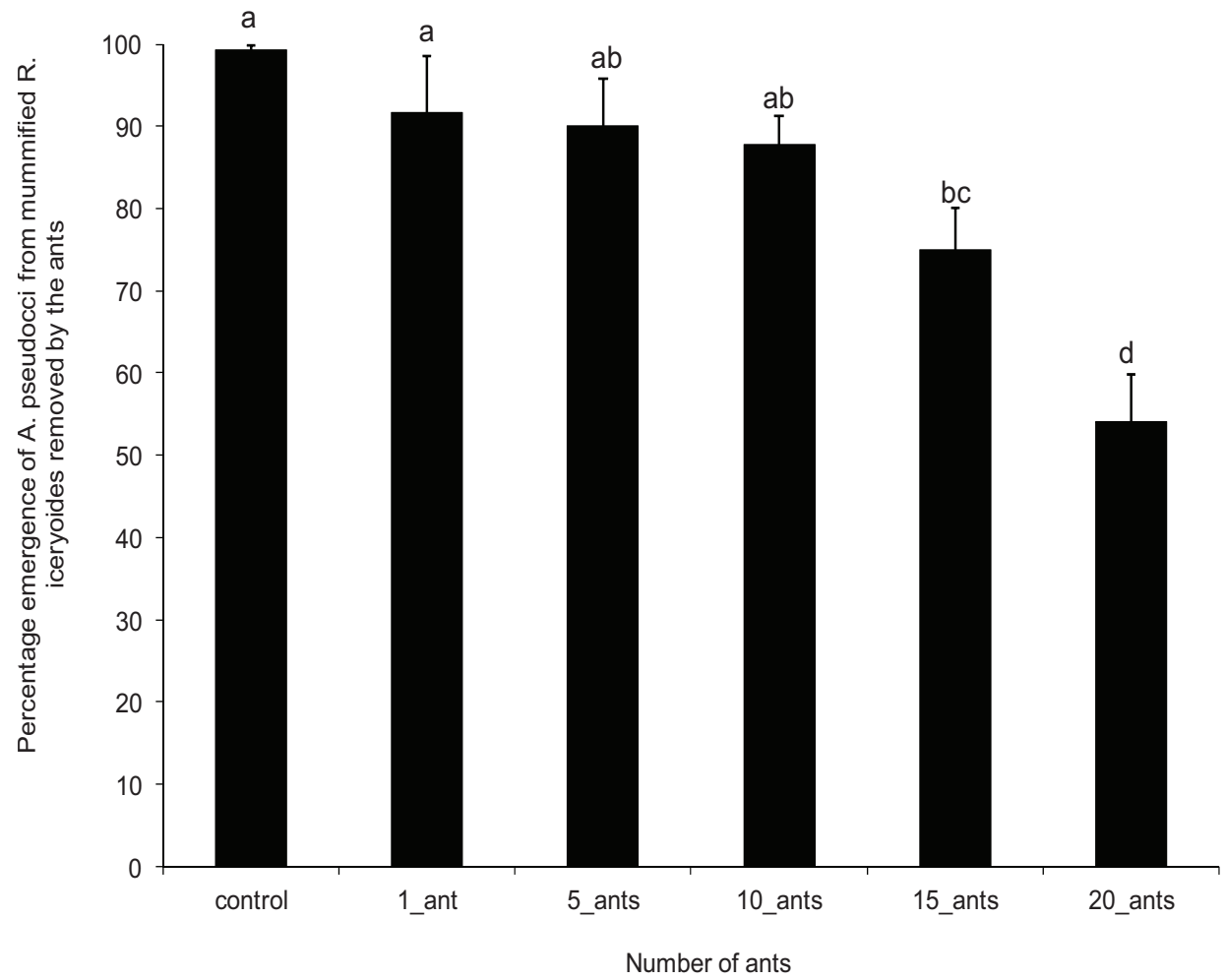

Figure 3. Mean ( \pm standard error) percentage of Anagyrus pseudococci emerged from mummified Rastrococcus iceryoides removed by the different Oecophylla longinoda groups for a period of $2 \mathrm{~h}$. Means with different letters are significantly different at $p \leqslant 0.05$.

\subsection{Mortality of A. pseudococci by O. longinoda and Parasitoid Behaviour Displayed to Evade Encounters}

The mean number of $O$. longinoda on $R$. iceryoides-infested butternut over the $2 \mathrm{~h}$ observation period ranged from $16.2 \pm 1.0$ to $23.1 \pm 1.68$ (Figure 4 ). Encounters between the ants and the host-seeking parasitoids were random rather than oriented search by the ants. The ants were frequently observed to exhibit aggressive behaviour towards A. pseudococci at every encounter. When confronted with the parasitoid, the ant workers detected them from a distance, opened their mandibles, and seized the parasitoid rapidly by a rapid forward movement of the whole body (Figure 5). Sometimes, O. longinoda workers were observed to exhibit reserved behavioural traits by walking more speedily and fluidly, allowing them to capture ovipositing female parasitoids. When the host-seeking A. pseudococci was successfully seized by O. longinoda workers using their mandibles, the parasitoids were sometimes released and picked up again immediately by the same or other ant workers. This repeated capture and recapture of the same parasitoids resulted in serious injury and sometimes eventual death of the parasitoid. The ant workers were found to remain still with captured parasitoids for some time before transporting them away (Figure 5). The highest number of parasitoids was killed at the 40th min and the lowest at the 120th min (Figure 4). There was a significant difference in the number of dead parasitoids caused by the ants over the $2 \mathrm{~h}$ period $(F=423.79 ; \mathrm{df}=1,349 ; p<0.0001)$ compared to the control. Figure 4 illustrates the trend in the number of parasitoids killed in the presence of ants over the $2 \mathrm{~h}$ period. The results suggest a highly significant interaction of parasitoids killed with time $(F=11.64 ; \mathrm{df}=9,119 ; p=0.0053)$. 


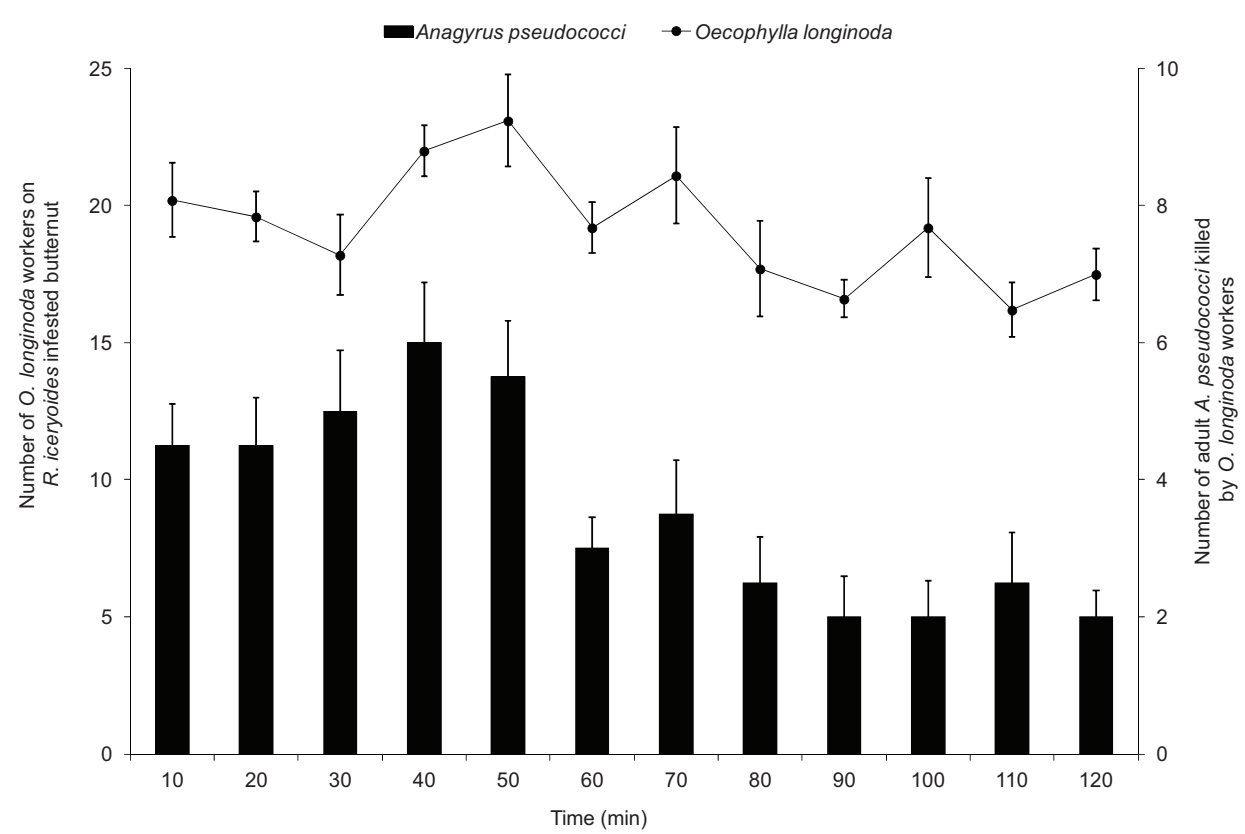

Figure 4. Mean ( \pm standard error) number of Oecophylla longinoda on Rastrococcus iceryoides-infested butternuts and mean number of adult Anagyrus pseudococci killed by Oecophylla longinoda workers in the foraging cages at $10 \mathrm{~min}$ intervals over a $2 \mathrm{~h}$ observation period.
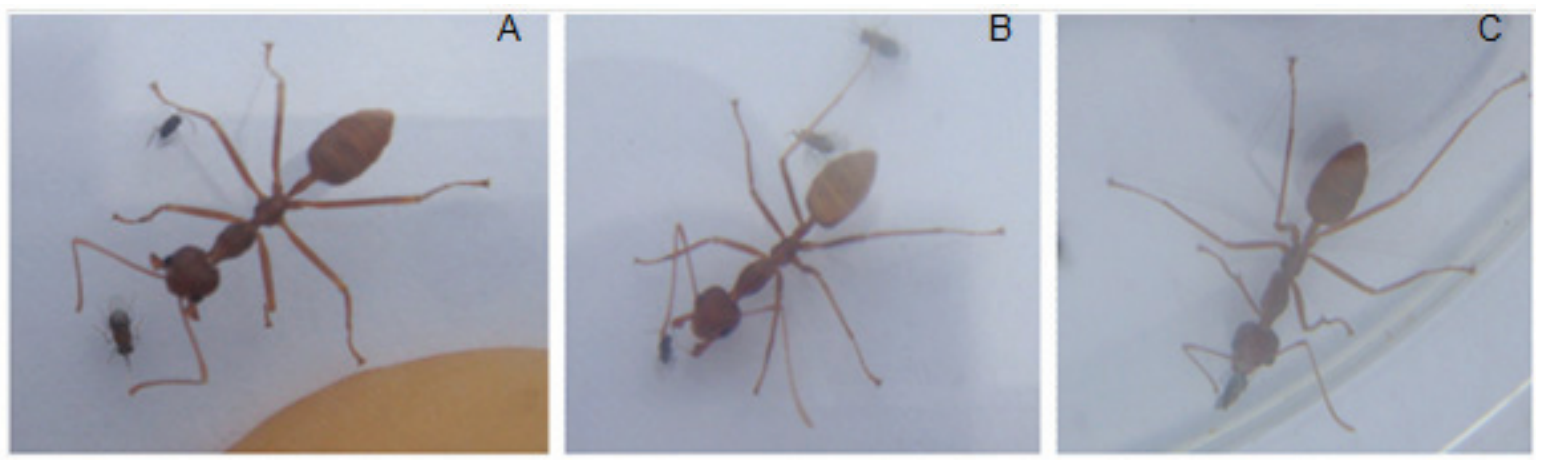

Figure 5. Oecophylla longinoda worker aggressively targets a fast running parasitoid (A); destabilizes it using its antenna (B) and finally seized the wasp with its mandibles (C).

However, O. longinoda workers sometimes failed to seize the parasitoid wasps because they efficiently escaped from the ants' grip during encounters or because the ant workers avoided or seemed not to be interested in the parasitoid. Escape behavior of the parasitoid wasps consisted of either jumping away with the highest response achieved at the 50th $\min (36.2 \pm 0.89$ observations) and to continue searching elsewhere on the R. iceryoides-infested butternut or flew away (highest values observed at the 50th min with $30.5 \pm 1.12$ observations) from the test arena in a direction putting them as far as possible from the ants (Figure 6). Ovipositing A. pseudococci were often observed to ignore approaching ants especially at the 40th $\min (22.9 \pm 1.44$ observations) and continued with the egg laying (Figure 6). The most common tactic used by the parasitoid to evade encounters with approaching ant workers was by retreating or repeatedly changing their walking direction (48.5 \pm 1.59 and $49.7 \pm 1.65$ observations at the 40th and 60th $\mathrm{min}$, respectively). The behavioural responses displayed by $A$. pseudococci on encounter with approaching ant workers varied significantly over the $2 \mathrm{~h}$ observation period $(F=8.13 ; \mathrm{df}=33,396 ; p<0.0001)$. 


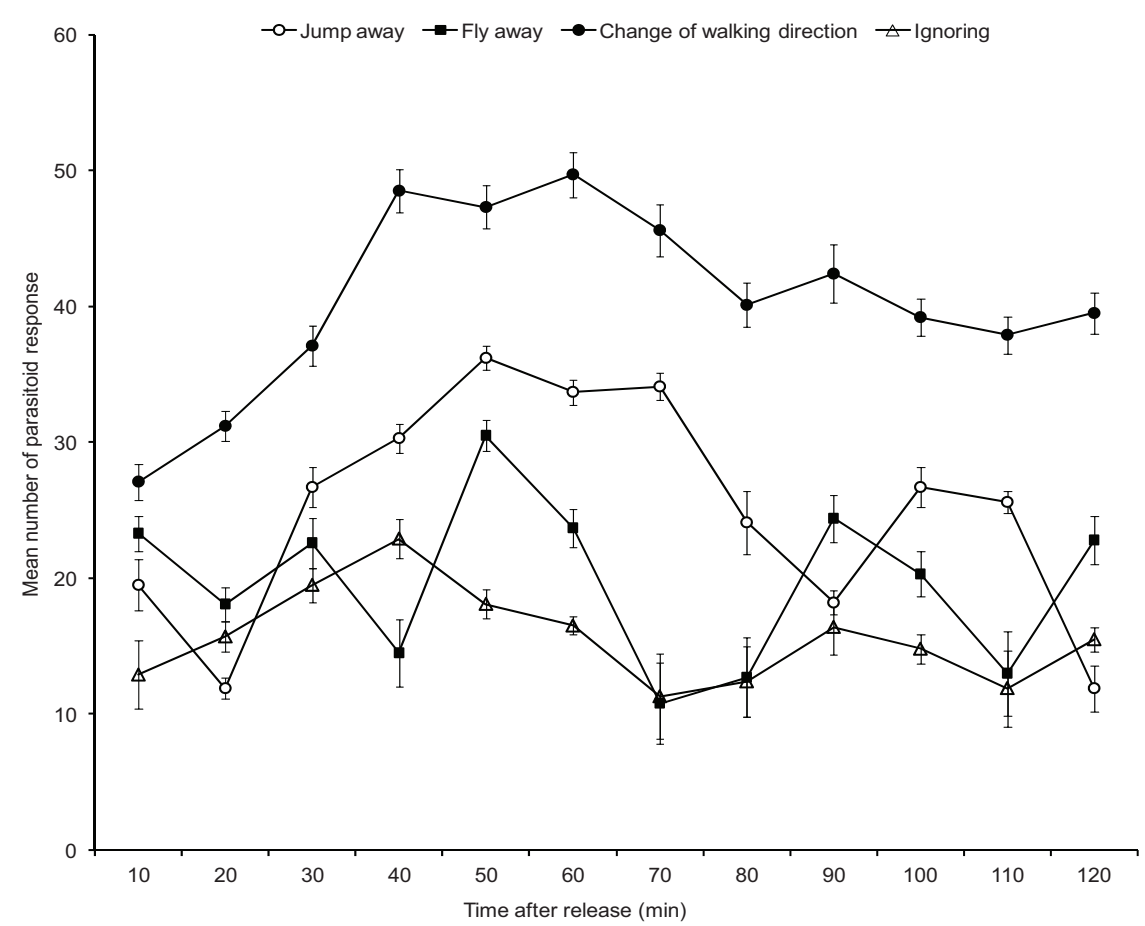

Figure 6. The mean ( \pm standard error) number of behavioural responses displayed by the parasitoid Anagyrus pseudococci to evade encounters and attacks by Oecophylla longinoda at 10 min intervals over a $2 \mathrm{~h}$ observation period.

\section{Discussion}

Rastrococcus iceryoides is the most important mealybug pest of mango in East Africa [1,3,4], and A. pseudococci is the only major parasitoid we have routinely recovered from this invasive pest in Kenya and Tanzania [4]. Anagyrus pseudococci is thus of potential importance not only in the natural regulation of this pest but as a candidate for biological control programs that may be contemplated in the future. Although the efficiency of $A$. pseudococci in decreasing populations of several other mealybug species on their host plants has been well documented [50-55], this is the first comparable study with the mango mealybug $R$. iceryoides.

The offspring sex ratio was more female-biased in the "ant-excluded" treatment compared to the "ant-tended" treatments. Casual observations showed that sometimes there were physical contacts between the parasitoids seeking to utilize the host and the foraging ants. These interactions interrupted the parasitoids during ovipositor probing and drilling. The behavioural response of the parasitoid in the presence of the ant could delay the flow of spermatozoa released from the spermatheca during the fertilization phase, thereby increasing the production of unfertilized eggs. Therefore, the production of less female biased sex ratio in the presence of the ants may be attributed to the frequency of physical interference at the ovipositing site, as observed in the present study. Additional tests would be required to evaluate the role of these tactile interferences in the mechanisms by which female parasitoids change their offspring sex ratio in response to the presence of ants in a host-patch. In accordance to our study, findings by Boulton et al. [56] have also provided evidence to suggest that interference by male parasitoids (mating and/or harassment) during oviposition phase can completely disrupt facultative sex allocation, resulting in a less female-biased sex ratio because of female parasitoid inability to fertilize eggs. This is also similar to what was observed in Caraphractus cinctus (Walter) (Hymenoptera: Mymaridae) and Nasonia vitripennis (Hymenoptera: Pteromalidae), with the production of more male offsprings in the progeny in response to the frequency of physical and/or olfactory interference with other female (s) at the ovipositing sites [57,58]. Our findings 
have major implications for field releases of the parasitoids, since interference by the ants during the oviposition phase strongly influences the production of a more male-biased sex ratio.

In the present study, there is evidence of acceptability and suitability of $R$. iceryoides as host by the parasitoid $A$. pseudococci. This can be explained in part by the remarkable high level of parasitism (87\%) and emergence (95\%) achieved in the absence of the ants. This high level of parasitism and emergence can be attributed to the physiological compatibility between $R$. iceryoides and A. pseudococci [16], as the parasitoid does seem to share an evolutionary history with $R$. iceryoides (of Asian origin). The high percentage of parasitism observed in this study can also be attributed to short host-handling time by the parasitoid, which is beneficial because it increases the probability that the host will not escape before the egg is deposited. The efficiency of parasitism by A. pseudococci in the presence of the ants was found to diminish, although the parasitoid was able to gain access to the ant-protected resources and oviposit successfully in $R$. iceryoides by moving swiftly and avoiding encounters with approaching ants. This is in agreement with other studies that have noted a strong correlation between rapid host-handling time by $A$. pseudococci $[37,59]$ or other parasitoid species with reduced success on ant-attended treatments $[43,60]$. This is further supported by several other studies, which point out that the activities of natural enemies of mealybugs are often disrupted by some species of tending ants, compromising the parasitization potential of mealybugs' natural enemies and inducing further outbreaks of these economically important pests $[36,37,61]$. The mutualistic relationship between some ants and mealybug species is linked to the mealybugs' honeydew, which constitutes an important food resource for ants, implying that the latter are capable of employing strong territorial defences and aggressive tendencies that might end up disrupting or killing parasitoids and/or predators just to protect the mealybugs [4,62].

The number of mummified mealybugs removed during the experiment was observed to increase with an increase in the number of ant workers. This implies that the ants might be capable of causing a significant reduction in the parasitoid's immature life-stages. It is important to note that following antennal examination, ant workers were able to discriminate and selectively remove mummified $R$. iceryoides among unparasitized mealybugs and sterile sand grains. The role of the antennae in food finding by $O$. longinoda has been comprehensively described by Hölldobler and Wilson [39], which involves an elaborate tactile display as observed in our study. The worker ants transporting the mummified R. iceryoides were always trailed around by several other workers that finally come together, and on more than one occasion, they were observed pulling apart and dismantling mummies with their mandibles. The mutilation of mummified $R$. iceryoides by the ant workers is primarily a direct relationship resulting from the ants' interest in associated mummified $R$. iceryoides. When the mummified R. iceryoides removed by the ant workers were incubated, the percentage of adult eclosion was significantly reduced due to the damage inflicted on the parasitoid immature stages in the host compared to the control. A few mummies had large ragged-edged holes chewed into their dorsal or lateral surfaces, which suggests that some ant workers with their strong chewing mouthparts might have been responsible for the mummy predatory attempts. The importance of ant predation on parasitized insect species as a protein food source to complement their carbohydrate-rich diet has been widely documented [63-66]. The underlying ability of ant species to detect and selectively removed parasitized insects can be attributed in part to the alarm pheromones released by parasitized insects [67] or changes in the insect's behavior when it is parasitized [68,69].

Many studies have shown that workers of more aggressive ant species often attack and kill adult female parasitoids [37,70]. Anagyrus species near pseudococci Girault (Hymenoptera: Encyrtidae) has been reported to suffer high direct mortality when exposed to Anoplolepis steingroeveri Forel (Hymenoptera: Formicidae), Crematogaster peringueyi Emery (Hymenoptera: Formicidae) and Linepithema humile (Mayr) (Hymenoptera: Formicidae) [37]. In the current study, A. pseudococci also suffered significantly high direct mortality due to encounters with O. longinoda workers, which led to a quick decline in parasitoid populations over time. The majority of the parasitoids in this study were seized and killed during the process of oviposition as they concentrated every effort on subduing the 
host rather than the reactions of the nearby intruding ants. This is similar to the observation made by Mgocheti and Addison [37], who reported that Anagyrus sp. were readily seized by ants when they got entangled with the host while ovipositing as they struggled to retract their ovipositor. This implies that the detrimental effect of $O$. longinoda workers on the parasitoid wasps will be more severe with increased ant populations considering that they are highly organized aggressive predators with extensive foraging activities throughout the areas occupied by their colonies, and they have a high potential to expand into new areas.

It is apparent that $O$. longinoda did not only interfere with the percentage of parasitism of their adopted $R$. iceryoides, but also reduced $A$. pseudococci abundance by causing direct mortality and low reproductive success. This is not unexpected because the negative effect of $O$. longinoda on other insect species reported by various authors $[23,27,30,38,71]$ is also seen for mango mealybug parasitoids as presented here. It is important to mention here that the presence of the ant did not completely inhibit parasitoid landing and parasitism of $R$. iceryoides and it is possible that, with time, the parasitoid may be able to adapt to the presence of the ant and co-exist with it. However, while open-field studies are needed to validate our findings, future field releases of parasitoids to control mango mealybug infestation should be done with great caution taking into account the potential for biotic interference between the two natural enemies if both are recommended for use within the same agro-ecosystem.

Although we did not investigate the effect of semiochemicals produced by O. longinoda in the protection of R. iceryoides against parasitization by the parasitoid wasp, Appiah et al. [38] has clearly demonstrated that the presence of ant-produced semiochemicals on fruits and fruit trees both in the laboratory and opened field cages, respectively, had a negative effect on the searching behavior of parasitoids, thereby limiting their oviposition success on target hosts. This could be similar in the $O$. longinoda and A. pseudococci system leading to the evolution of avoidance behavior by the parasitoid at a distance from the aggressive ants, and this will further negatively impact on the efficiency of the parasitoids in the present study. Given that, in agricultural and natural ecosystems, $O$. longinoda obtains carbohydrate-rich honeydew from $R$. iceryoides that serves as a metabolic fuel for the ants, they will always exhibit protected behavioural dominance and promote the latter's infestation to economically unacceptable levels. Therefore, mango growers should engage in orchard management practices that improve and conserve natural and augmentative released populations of this parasitoid species to suppress R. iceryoides populations. In this regard, ant control or reduced ant populations in orchards should be considered a priority when parasitoids are to be used as biological control agents of hemipteran pests as ant presence will not only affect parasitoid abundance but also reproductive success and possibly the oviposition strategy of female parasitoids.

\section{Conclusions}

Although, open-field studies are needed to validate our findings, ongoing field releases of parasitoids in different agro-ecosystems for pest control must take into account the potential negative effect of $O$. longinoda to minimize the occurrence of biotic interference. Whether the impact observed in the current study will affect co-existence of the two natural enemies in the field depends on several factors. Firstly, the concentration and composition of O. longinoda population on the different host plants with populations of the invasive mealybug $R$. iceryoides and how the parasitoid A. pseudococci respond to it will be crucial. Secondly, it is possible that the response of the parasitoid to ants attack may be a learned response that varies with the frequency of interactions between the parasitoid and the ant. Indeed, not all interactions between foragers and ant antagonists were necessarily fatal and in non-fatal encounters, the forager could benefit from learning the extent of the danger of such an interaction. Thirdly, the level of co-evolution between the natural enemies and their resident ant species as well as host plants may also contribute to variation in the strength of trait-mediated interactions. 
Acknowledgments: This research was supported by a grant from the German Federal Ministry for Economic Cooperation and Development (BMZ) to the icipe African Fruit Fly Programme (AFFP) and by the German Academic Exchange Service (DAAD) scholarship to the senior author through the African Regional Postgraduate Programme in Insect Science (ARPPIS). We are grateful to the two anonymous reviewers whose comments substantially improved the manuscript. We are thankful to D. Salifu for helping with the statistical analyses.

Author Contributions: The initial idea of the study was conceived by Sunday Ekesi, Samira Mohamed and Tanga Mbi. Samira Mohamed and Sunday Ekesi assisted with the design of experimental protocol. Tanga Mbi and Peterson Nderitu collected the ants used in the study and performed the experimental protocol. Tanga Mbi and Sunday Ekesi drafted the manuscript with substantial help from Samira Mohamed. Prem Govender also interpreted the data and gave valuable comments on the manuscript. All authors read and approved the final manuscript.

Conflicts of Interest: The authors declare no conflict of interest.

\section{References}

1. Williams, D.J. The mealybug genus Rastrococcus Ferris (Hemiptera: Pseudococcidae). J. Syst. Entomol. 1989, 14, 433-486. [CrossRef]

2. Luhanga, W.W.; Gwinner, J. Mango mealybug (Rastrococcus iceryoides) on Mangifera indica in Malawi. FAO Plant Prot. Bull. 1993, 41, 125-126.

3. CABI. Crop Protection Compendium. In Global Module, 2nd ed.; CAB International Publishing: Wallingford, UK, 2000.

4. Tanga, M.C. Bio-Ecology of the Mango Mealybug, Rastrococcus iceryoides Green (Hemiptera: Pseudococcidae) and Its Associated Natural Enemies in Kenya and Tanzania. Ph.D. Thesis, University of Pretoria, Pretoria, South Africa, 2012.

5. Moore, D. Biological control of Rastrococcus invadens. Biocontrol News Inf. 2004, 25, 17-27.

6. Agounké, D.; Agricola, U.; Bokonon-Ganta, A. Rastrococcus invadens Williams (Hemiptera, Pseudococcidae), a serious exotic pest of fruit trees and other plants in West Africa. Bull. Entomol. Res. 1988, 78, 695-702. [CrossRef]

7. Ben-Dov, Y. A Systematic Catalogue of the Mealybugs of the World (Insecta: Homoptera: Coccoidea: Pseudococcidae and Putoidae) with Data on Geographical Distribution, Host Plants, Biology and Economic Importance; Intercept Limited: Andover, UK, 1995; pp. 435-436.

8. Bokonon-Ganta, A.H.; de Groote, H.; Neuenschwander, P. Socio-economic impact of biological control of mango mealybug in Benin. Agric. Ecosyst. Environ. 2002, 93, 367-378. [CrossRef]

9. Schabel, H.G. Forest Entomology in East Africa: Forest Insects of Tanzania; Springer: Berlin, Germany, 2006; p. 328.

10. Rawat, R.R.; Jakhmola, S.S. Bionomics of the mango-coccid (Rastrococcus iceryoides Green; Homoptera, Coccidae). Indian J. Agric. Sci. 1970, 40, 140-144.

11. CPC. Crop Protection Compendium Database; CAB International: Wallingford, UK, 2002.

12. Kairo, M.T.K.; Pollard, G.V.; Peterkin, D.D.; Lopez, V.F. Biological control of the hibiscus mealybug, Maconellicoccus hirsutus Green (Hemiptera: Pseudococcidae) in the Caribbean. Integr. Pest Manag. Rev. 2000, 5, 241-254. [CrossRef]

13. Meyerdirk, D.E.; Warkentin, R.; Attavian, B.; Gersabeck, E.; Francis, A.; Adams, M.; Francis, G. Biological Control of the Pink Hibiscus Mealybug Project Manual; United States Department of Agriculture: Washington, DC, USA, 1998.

14. McKenzie, H.L. Mealybugs of California with Taxonomy, Biology and control of North American Species (Homoptera: Coccoidea: Pseudococcidae); University of California Press: Berkeley, LA, USA, 1967; p. 534.

15. Sagarra, L.A.; Peterkin, D.D. Invasion of the Carribean by the hibiscus mealybug, Maconellicoccus hirsutus Green (Homoptera: Pseudococcidae). Phytoprotection 1999, 80, 103-113. [CrossRef]

16. Tanga, M.C.; Samira, A.M.; Govender, P.; Ekesi, S. Effect of host plant on bionomics and life history parameters of Anagyrus pseudococci (Hymenoptera: Encyrtidae), a parasitoid of the mango mealybug Rastrococcus iceryoides (Homoptera: Pseudococcidae). Biol. Control 2012, 65, 43-52. [CrossRef]

17. Van Wijngaarden, P.M.; van Kessel, M.; van Huis, A. Oecophylla longinoda (Hymenoptera: Formicidae) as a biological control agent for cocoa capsids (Hemiptera: Miridae). Proc. Neth Entomol. Soc. Meet. 2007, 18, 21-30. 
18. Van Mele, P. A historical review of research on the weaver ant Oecophylla in biological control. Agric. For. Entomol. 2008, 10, 13-22. [CrossRef]

19. Carroll, C.R.; Janzen, D.H. Ecology of foraging by ants. Annu. Rev. Ecol. Evol. Syst. 1973, 4, $231-257$. [CrossRef]

20. Hölldobler, B.; Wilson, E.O. The Ants; The Belknap Press of Harvard University Press: Cambridge, MA, USA, 1990; p. 732.

21. Jiggins, C.; Majerus, M.E.N.; Gough, U. Ant defence of colonies of Aphis fabae. Br. J. Entomol. Nat. Hist. 1993, 6, 129-137.

22. Buckley, R.C. Interactions involving plants, Homoptera, and ants. Ann. Ecol. Syst. 1987, 18, 111-135. [CrossRef]

23. Wimp, G.M.; Whitham, T.G. Biodiversity consequences of predation and host plant hybridization on an aphid-ant mutualism. Ecology 2001, 82, 440-452.

24. Martinez-Ferrer, M.T.; Grafton-Cardwell, E.E.; Shorey, H.H. Disruption of parasitism of the California red scale (Homoptera: Diaspididae) by three ant species (Hymenoptera: Formicidae). Biol. Control 2003, 26, 279-286. [CrossRef]

25. Chacón, J.M.; Landis, D.A.; Heimpel, G.E. Potential for biotic interference of a classical biological control agent of the soybean aphid. Biol. Control 2008, 46, 216-225. [CrossRef]

26. Goeden, R.D.; Louda, S.M. Biotic interference with insects imported for weed-control. Ann. Rev. Entomol. 1976, 21, 325-342. [CrossRef]

27. Van Mele, P.; Vayssières, J.F.; van Tellingen, E.; Vrolijks, J. Effects of an African weaver ant, Oecophylla longinoda, in controlling mango fruit flies (Diptera: Tephritidae) in Benin. J. Econ. Entomol. 2007, 100, 695-701. [CrossRef] [PubMed]

28. Van Mele, P.; Cuc, N.T.T.; van Huis, A. Direct and indirect influences of the weaver ant Oecophylla smaragdina on citrus farmers' pest perceptions and management practices in Mekong Delta, Vietnam. Int. J. Pest Manag. 2002, 48, 225-232. [CrossRef]

29. Ayenor, G.K.; Röling, N.G.; Padi, B.; van Huis, A.; Obeng-Ofori, D.; Atengdem, P.B. Converging farmers' and scientists' perspectives on researchable constraints on organic cocoa production in Ghana: Results of a diagnostic study. NJAS Wagening. J. Life Sci. 2004, 52, 261-284. [CrossRef]

30. Offenberg, J.; Havanon, S.; Aksornkoae, S.; Macintosh, D.; Nielsen, M.G. Observations on the ecology of weaver ants (Oecophylla smaragdina Fabricius) in a Thai mangrove ecosystem and their effect on herbivory of Rhizophora mucronata Lam. Biotropica 2004, 36, 344-351. [CrossRef]

31. Peng, R.K.; Christian, K. The weaver ant, Oecophylla smaragdina (Hymenoptera: Formicidae), an effective biological control agent of the red-banded thrips, Selenothrips rubrocinctus (Thysanoptera: Thripidae) in mango crops in the Northern Territory of Australia. Int. J. Pest Manag. 2004, 50, 107-114. [CrossRef]

32. Peng, R.K.; Christian, K.; Reilly, D. Weaver ants, Oecophylla smaragdina (Hymenoptera: Formicidae), as bio-control agents on African mahogany trees, Khaya senegalensis (Sapindales: Meliaceae), in the Northern Territory of Australia. Int. J. Pest Manag. 2010, 56, 363-370. [CrossRef]

33. Sinzogan, A.A.C.; van Mele, P.; Vayssières, J.F. Implications of on-farm research for local knowledge related to fruit flies and the weaver ant Oecophylla longinoda in mango production. Int. J. Pest Manag. 2008, 54, 241-246. [CrossRef]

34. Way, M.J.; Khoo, K.C. Role of ants in pest management. Ann. Rev. Entomol. 1992, 37, 479-503. [CrossRef]

35. Kaplan, I.; Eubanks, M.D. Disruption of cotton aphid (Homoptera: Aphididae)-natural enemy dynamics by red imported fire ants (Hymenoptera: Formicidae). Environ. Entomol. 2002, 31, 1173-1183. [CrossRef]

36. Daane, K.M.; Sime, K.R.; Fallon, J.; Cooper, M.L. Impacts of Argentine ants on mealybugs and their natural enemies in California's coastal vineyards. Ecol. Entomol. 2007, 32, 583-596. [CrossRef]

37. Mgocheki, N.; Addison, P. Interference of ants (Hymenoptera: Formicidae) with biological control of the vine mealybug Planococcus ficus (Signoret) (Hemiptera: Pseudococcidae). Biol. Control 2009, 49, 180-185. [CrossRef]

38. Appiah, E.F.; Ekesi, S.; Afreh-Nuamah, K.; Obeng-Ofori, D.; Mohamed, S.A. African weaver ant-produced semiochemicals impact on foraging behavior and parasitism by the Opiine parasitoid, Fopius arisanus on Bactrocera invadens (Diptera: Tephritidae). Biol. Control 2014, 79, 49-57. [CrossRef]

39. Hölldobler, B.; Wilson, E.O. The multiple recruitment systems of the African weaver ant Oecophylla longinoda (Latreille) (Hymenoptera: Formicidae). Behav. Ecol. Sociobiol. 1978, 3, 19-60. [CrossRef] 
40. Whitehead, V.B. A Study of the Predators and Parasites of Planococcus citri (Risso) (Homoptera: Pseudococcidae) on Vines in the Western Cape Province, South Africa. Master's Thesis, Rhodes University, Grahamstown, South Africa, 1957.

41. Van Lenteren, J.C. Oviposition Behavior of Aphytis. In Advances in the Study of Aphytis; Rosen, D., Ed.; Intercept: Andover, MA, USA, 1994; pp. 13-40.

42. Barzman, M.S.; Daane, K.M. Host-handling behaviours in parasitoids of the black scale: A case for ant-mediated evolution. J. Anim. Ecol. 2001, 70, 237-247.

43. Way, M.J. Studies on the association of the ant Oecophylla longinoda (Latr.) (Formicidae) with the scale insect Saissetia zanzibarensis Williams (Coccidae). Bull. Entomol. Res. 1954, 45, 113-134. [CrossRef]

44. Islam, K.S.; Copland, M.J.W. Host preference and progeny sex ratio in a solitary koinobiont mealybug endoparasitoids, Anagyrus pseudococci (Girault) in response to its host stage. Biocontrol. Sci. Technol. 1997, 7, 449-456. [CrossRef]

45. Lacey, E.P. What is an adaptive environmentally induced parental effect? In Maternal Effects as Adaptations; Mousseau, T.A., Fox, C.W., Eds.; Oxford University Press: New York, NY, USA, 1998; pp. 54-66.

46. Van Kessel, M.; van Wijngaarden, M. The Behaviour of Oecophylla longinoda. How to Manipulate or Use Oecophylla Ants in Cocoa Agro-Ecosystems in Order to Suppress Cocoa Pests Such as Capsids? Ph.D. Thesis, Wageningen University, Wageningen, The Netherlands, 2006.

47. Rosenheim, J.A.; Rosen, D. Foraging and oviposition decisions in the parasitoid Aphytis lingnanensis: Distinguishing the influences of egg load and experience. J. Anim. Ecol. 1991, 60, 873-893. [CrossRef]

48. Rousse, P.; Chiroleu, F.; Veslot, J.; Quilici, S. The host and microhabitat olfactory location by Fopius arisanus suggests a broad potential host range. Physiol. Entomol. 2007, 32, 313-321. [CrossRef]

49. $\mathrm{R}$ Development Core Team. The $\mathrm{R}$ Project for Statistical Computing. Available online: http:/ / www.R-project.org/ (accessed on 21 July 2015).

50. Malakar-Kuenen, R.; Daane, K.M.; Godfrey, K.E.; Ball, J.C.; Bentley, W.J.; Yokota, G.Y.; Martin, L.A.; Godfrey, K.; Ball, J. Population dynamics of the vine mealybug and its natural enemies in the Coachella and San Joaquin Valleys. Univ. Calif. Plant Prot. Q. 2001, 11, 1-3.

51. Trjapitzin, S.V.; Trjapitzin, V.A. Parasitoids of the mealybugs on cultivated grapes in Argentina, with description of a new species of the genus Aenasius Walker (Hymentoptera: Encrytidae). Entomol. Obozr. 2002, 76, 174-179.

52. Walton, V.M. Development of an Integrated Pest Management System for Vine Mealybug, Planococcus citrus (Signoret), in Vineyards in the Western Cape Province, South Africa. Ph.D. Thesis, University of Stellenbosch, Stellenbosch, South Africa, 2003.

53. Walton, V.M.; Daane, K.M.; Bentley, W.J.; Millar, J.G.; Larsen, T.E.; Malakar-Kuenen, R. Pheromone-based mating disruption of Planococcus ficus (Hemiptera: Pseudococcidae) in California vineyards. J. Econ. Entomol. 2006, 99, 1280-1290. [CrossRef] [PubMed]

54. Triapitsyn, S.V.; Gonzalez, D.; Vickerman, D.B.; Noyes, J.S.; White, E.B. Morphological, biological and molecular comparisons among the different geographical populations of Anagyrus pseudococci (Hymenoptera: Encyrtidae), parasitoids of Planococcus spp. (Hemiptera: Pseudococcidae), with notes on Anagyrus dactylopii. Biol. Control 2007, 41, 14-24. [CrossRef]

55. Mahfoudhi, N.; Dhouibi, M.H. Survey of mealybugs (Hemiptera: Pseudococcidae) and their natural enemies in Tunisian vineyards. Afr. Entomol. 2009, 17, 154-160. [CrossRef]

56. Boulton, R.A.; Collins, L.A.; Shuker, D.M. Beyond sex allocation: The role of mating systems in sexual selection in parasitoid wasps. Biol. Rev. 2014, 90, 599-627. [CrossRef] [PubMed]

57. Wylie, H.G. Interference among females of Nasonia vitripennis (Hymenoptera: Pteromalidae) and its effect on sex ratio of their progeny. Can. Entomol. 1976, 108, 655-661. [CrossRef]

58. Jackson, D.J. Observation on the biology of Caraphractus cinctus (Walter) (Hymenoptera: Mymaridae), a parasitoid of the eggs of Dysticidae (Coleoptera). III. The adult life and sex ratio. Trans. R. Entomol. Soc. Lond. 1966, 118, 23-49. [CrossRef]

59. Hcidari, M.; Jahan, M. A study of ovipositional behaviour of Anagyrus pseudococci a parasitoid of mealybugs. J. Agric. Sci. Technol. 2000, 2, 49-53.

60. Flanders, S.E. The role of the ant in the biological control of homopterous insects. Can. Entomol. 1951, 83, 93-98. [CrossRef] 
61. Tollerup, K.; Rust, M.K.; Klotz, J.H. Formica perpilosa, an emerging pest in vineyards. J. Agric. Urban Entomol. 2007, 24, 147-158. [CrossRef]

62. Mansour, R.; Gaetana, M.; Alessandra, L.P.; Kaouthar, G.L.; Agatino, R. A survey of scale insects (Hemiptera: Coccoidea) and tending ants in Tunisian vineyards. J. Plant Prot. Res. 2012, 51, 197-203. [CrossRef]

63. Vinson, S.B.; Scarborough, T.A. Interaction between Solenopsis invicta (Hymenoptera: Formicidae), Rhopalosiphum maidis (Homoptera: Aphididae) and the parasitoid Lysiphlebus testaceipes Cresson (Hymenoptera: Aphidiidae). Ann. Entomol. Soc. Am. 1991, 84, 158-164. [CrossRef]

64. Michaud, J.P. Sources of mortality in colonies of brown citrus aphid Toxoptera citricida. BioControl 1999, 44, 347-367. [CrossRef]

65. Hill, S.L.; Hoy, M.A. Interactions between the red imported fire ant Solenopsis invicta and the parasitoid Lipolexis scutellaris potentially affecting a classical biological control agent of the aphid Toxoptera citricida. Biol. Control 2003, 27, 11-19. [CrossRef]

66. Shiojiri, K.; Takabayashi, J. Parasitoid preference for host-infested plants in affected by the risk of intraguild predation. J. Insect Behav. 2005, 18, 567-576. [CrossRef]

67. Nault, L.R.; Montogomery, M.E.; Bowers, W.S. Ant-aphid association: Role of aphid alarm pheromone. Science 1976, 192, 1349-1351. [CrossRef] [PubMed]

68. Gardner, S.M.; Ward, S.A.; Dixon, A.F.G. Limitation of superparasitism by Aphidius rhopalosiphi: A consequence of aphid defensive behavior. Ecol. Entomol. 1984, 9, 149-155. [CrossRef]

69. Gerling, D.; Roitberg, B.D.; Mackauer, M. Instar-specific defense of the pea aphid, Acyrthosiphon pisum: Influence on oviposition success of the parasite Aphelinus asychis. J. Insect Behav. 1990, 3, 501-514. [CrossRef]

70. Buckley, R.; Gullan, P. More aggressive ant species (Hymenoptera: Formicidae) provide better protection for soft scale and mealybugs (Homoptera: Pseudococcidae). Biotropica 1991, 23, 282-286. [CrossRef]

71. Jahn, G.C.; Beardsley, J.W.; González-Hernández, H. A review of the association of ants with mealybug wilt disease of pineapple. Proc. Hawaii Entomol. Soc. 2003, 36, 9-28.

(C) 2015 by the authors; licensee MDPI, Basel, Switzerland. This article is an open access article distributed under the terms and conditions of the Creative Commons by Attribution (CC-BY) license (http:/ / creativecommons.org/licenses/by/4.0/). 